\title{
A Theoretical Integration within Obsessive- Compulsive Disorder (OCD) and Dissociative Spectrums: Obsessional Dissociation
}

\author{
Abdullah Yıldırım, $\mathrm{MD}^{1^{*}}$, Murat Boysan, $\mathrm{PhD}^{2}$ \\ ${ }^{1}$ Department of Psychiatry, Kahramanmaraş Sütçü İmam University School of Medicine, Kahramanmaraş, Turkey \\ ${ }^{2}$ Department of Psychology, Faculty of Social Sciences, Van Yüzüncü Yıl University, Van, Turkey
}

\section{Dear Editor,}

Over the recent three decades, there has been a growing academic interest on significant associations between obsessive compulsive disorder (OCD) and dissociation (Belli, Ural, Vardar, Yesilyurt, \& Oncu, 2012; Belli et al., 2013; Fontenelle et al., 2007; Norton, Ross, \& Novotny, 1990; Pica, Beere, \& Maurer, 1997). In this regard, while the relationships with checking, ordering and symmetry has been widely highlighted from the view of obsessive-compulsive symptoms (Goff, Olin, Jenike, Baer, \& Buttolph, 1992; Grabe et al., 1999; Lochner et al., 2004; Rufer, Fricke, Held, Cremer, \& Hand, 2006; Watson $\& W u, 2002 ;$ Watson, Wu, \& Cutshall, 2004), the role of absorption / imaginative involvement dimension of dissociative symptoms in the pathophysiology of OCD has been underscored (Aardema \& Wu, 2011; Paradisis, Aardema, \& Wu, 2015; Soffer-Dudek, 2014; SofferDudek, Lassri, Soffer-Dudek, \& Shahar, 2015; Tapancl, Yıldırım, \& Boysan, 2018). Nevertheless, to the best of our

\footnotetext{
*Correspondence: yldrmabdullahayahoo.com

Dr. Abdullah Yıldırım, Department of Psychiatry, Kahramanmaraş Sütçü Imam University School of Medicine, Kahramanmaraş, Turkey
}

Received: 17 January 2018 Accepted: 13 February 2018

Sleep and Hypnosis

Journal homepage:

www.sleepandhypnosis.org

ISSN: 2458-9101 (Online) opinion, a great deal of commonalities and transitions between these two phenomena exist. The overlapping features within these two clinical entities include heterogeneity of symptom structure (Boysan, 2016; Holmes et al., 2005; Mataix-Cols, do Rosario-Campos, \& Leckman, 2005; Waller, Putnam, \& Carlson, 1996), intrusiveness in nature (Boon, Steele, \& van der Hart, 2011; Clark, 2004), ubiquity in general population (Maaranen et al., 2008; Rachman \& De Silva, 1978; Ross, Joshi, \& Currie, 1990; Salkovskis \& Harrison, 1984; Vanderlinden, Van der Hart, \& Varga, 1996), serve as defense mechanism in response to heightened stress but become counterproductive in pathological levels (Boysan, 2015; Boysan, Goldsmith, Çavuş, Kayri, \& Keskin, 2009; Butler, Duran, Jasiukaitis, Koopman, \& Spiegel, 1996), significant linkages to developmental trauma (Chu, 2011; Lochner et al., 2002; Mathews, Kaur, \& Stein, 2008; Ogawa, Sroufe, Weinfield, Carlson, \& Egeland, 1997; Schimmenti \& Caretti, 2016), interpersonal aspects central to the etiological accounts (Aardema et al., 2013; Boysan \& Çam, 2016; Doron \& Kyrios, 2005; Doron et al., 2012; Guidano \& Liotti, 1983; Liotti, 2004), pronounced deficits in memory and attention (Giesbrecht, Lynn, Lilienfeld, \& Merckelbach, 2008; Muller \& Roberts, 2005), and transdiagnostic characteristics as the hallmark of the psychopathology (Abramowitz, McKay, \& Storch, 2017; Dell \& O'Neil, 2015; Kadak, Nasiroglu, Boysan, \& Aydin, 2013; Lanius et al., 2010). Therefore, more integrative 
models reflecting reconciliation and refinement across $O C D$ and dissociative spectrums are needed to more profoundly elaborate the overlapping features and distinctions between these two clinical phenomena.

In an attempt to integrate OCD and dissociative spectrums, the term 'obsessional dissociation', coined by Boysan, Yildirim, Besiroglu, Kefeli, and Kagan (2018), refers to fragmentation and dysfunction in normal integration of conscious awareness, memory process, emotional regulation, motor and behavioral control as maladaptive in reaction to intense mental engagement in intrusive obsessional thoughts. The Van Obsessional Dissociation Questionnaire (VOD-Q) was designed to assess a tendency to dissociate in response to intense obsessional engagement. In keeping with dissociation literature, the VOD-Q yields three subscales of 'Obsessional Absorption / Imaginative Involvement', 'Obsessional Depersonalization / Derealization' and 'Obsessional Amnesia'. The VOD-Q revealed sound and promising psychometric properties to distinguish patients with OCD from healthy controls. As expected, the VOD-Q global and subscale scores were significantly associated with aspects of obsessive-compulsive symptoms as measured by Padua Inventory - Revised (Besiroglu et al., 2005; Van Oppen, 1992), as well as dissociative symptomatology as indexed by the Dissociative Experiences Scale (Carlson \& Putnam, 1993; Yargic, Tutkun, \& Sar, 1995). The VOD-Q revealed an excellent internal reliability (Cronbach alphas ranged from 0.90 to

\section{References}

Aardema, F., Moulding, R., Radomsky, A. S., Doron, G., Allamby, J., \& Souki, E. (2013). Fear of self and obsessionality: Development and validation of the Fear of Self Questionnaire. Journal of Obsessive-Compulsive and Related Disorders, 2(3), 306-315. doi:10.1016/j.jocrd.2013.05.005

Aardema, F., \& Wu, K. D. (2011). Imaginative, dissociative, and schizotypal processes in obsessive-compulsive symptoms. Journal of Clinical Psychology, 67(1), 74-81. doi:10.1002/ jclp.20729

Abramowitz, J. S., McKay, D., \& Storch, E. A. (2017). The Wiley handbook of obsessive compulsive disorders: Wiley.

Belli, H., Ural, C., Vardar, M. K., Yesilyurt, S., \& Oncu, F. (2012). Dissociative symptoms and dissociative disorder comorbidity in patients with obsessive-compulsive disorder. Comprehensive Psychiatry, 53(7), 975-980. doi:10.1016/j. comppsych.2012.02.004
0.97) and temporal stability (two week test-retest intracorrelation coefficients ranged from 0.73 to 0.90 ).

Preliminary evidence showed that presence of obsessions may not be pathognomonic per se rather obsession-induced dissociation may play crucial role in transition of 'normal obsessions' to 'abnormal obsessions' or OCD (Boysan et al., 2018). The dissociative model of OCD provides an avenue to understand the etiological underpinnings of pathological $O C D$ in relation to dissociative symptomatology. Furthermore, the emerging evidence lending support for a dissociative subtype of OCD may probably have implications in opening new windows to integrate theoretical background of dissociative symptomatology with cognitive and behavioral models of $O C D$ in a more creative fashion which can promote encouragement to develop more effective therapeutic interventions for treatment of obsessive-compulsive and dissociative symptomatology. To this end, the Van Obsessional Dissociation Questionnaire, a psychometric tool designed to screen a tendency to dissociate in response to unwanted obsessive intrusions, is presented in the appendix for researchers and clinicians.

Acknowledgments: None declared.

Conflict of interest: The authors declare no conflict of interest.

Funding: The authors declare that the current study was not financially supported by any institution or organization.

Belli, H., Ural, C., Yesilyurt, S., Vardar, M. K., Akbudak, M., \& Oncu, F. (2013). Childhood trauma and dissociation in patients with obsessive compulsive disorder. West Indian Medical Journal, 62(1), 39-44. doi:West Indian Med J

Besiroglu, L., Agargun, M. Y., Boysan, M., Eryonucu, B., Gulec, M., \& Selvi, Y. (2005). The assessment of obsessive-compulsive symptoms: Reliability and validity of the Padua Inventory in Turkish population. Turkish Journal of Psychiatry, 16(3), 179189.

Boon, S., Steele, K., \& van der Hart, O. (2011). Coping with traumarelated dissociation: Skills training for patients and therapists: W. W. Norton \& Company.

Boysan, M. (2015). Dissociative experiences are associated with obsessive-compulsive symptoms in a non-clinical sample: a latent profile analysis. Archives of Neuropsychiatry, 51, 253262. 
Boysan, M. (2016). Associations between dissociation and posttraumatic stress response. In C. R. Martin, V. R. Preedy, \& V. B. Patel (Eds.), Comprehensive guide to post-traumatic stress disorder (pp. 1-16). New York, NY: Springer.

Boysan, M., \& Çam, Z. (2016). An investigation into the role of attachment insecurities in obsessive-compulsive symptoms. British Journal of Guidance \& Counselling, 1-16. doi:10.1080/0 3069885.2016.1262533

Boysan, M., Goldsmith, R. E., Çavuş, H., Kayri, M., \& Keskin, S. (2009). Relations among anxiety, depression, and dissociative symptoms: the influence of abuse subtype. Journal of Trauma \& Dissociation, 10(1), 83-101. doi:10.1080/15299730802485185

Boysan, M., Yildirim, A., Besiroglu, L., Kefeli, M. C., \& Kagan, M. (2018). Development and preliminary psychometric properties of an instrument for the measurement of obsessional dissociative experiences: the Van Obsessional Dissociation Questionnaire (VOD-Q). Psychiatric Quarterly. doi:https://doi. org/10.1007/s11126-017-9555-2

Butler, L. D., Duran, R. E., Jasiukaitis, P., Koopman, C., \& Spiegel, D. (1996). Hypnotizability and traumatic experience: a diathesisstress model of dissociative symptomatology. American Journal of Psychiatry, 153 (7 Suppl), 42-63. doi:10.1176/ ajp.153.8.A42

Carlson, E. B., \& Putnam, F. W. (1993). An update on the Dissociative Experiences Scale. Dissociation, 6, 16-27.

Chu, J. A. (2011). Rebuilding shattered lives: Treating complex PTSD and dissociative disorders. New York, NY: John Wiley \& Sons.

Clark, D. A. (2004). Cognitive-behavioral therapy for OCD. New York, NY: Guilford.

Dell, P. F., \& O'Neil, J. A. (2015). Dissociation and the dissociative disorders: DSM-V and beyond. New York, NY: Routledge.

Doron, G., \& Kyrios, M. (2005). Obsessive compulsive disorder: A review of possible specific internal representations within a broader cognitive theory. Clinical Psychology Review, 25(4), 415-432. doi:10.1016/j.cpr.2005.02.002

Doron, G., Moulding, R., Nedeljkovic, M., Kyrios, M., Mikulincer, M., \& Sar-El, D. (2012). Adult attachment insecurities are associated with obsessive compulsive disorder. Psychology and Psychotherapy-Theory Research and Practice, 85(2), 163-178. doi:10.1111/j.2044-8341.2011.02028.x

Fontenelle, L. F., Domingues, A. M., Souza, W. F., Mendlowicz, M. V., de Menezes, G. B., Figueira, I. L., \& Versiani, M. (2007). History of trauma and dissociative symptoms among patients with obsessive-compulsive disorder and social anxiety disorder. Psychiatric Quarterly, 78(3), 241-250. doi:10.1007/ s11126-007-9043-1

Giesbrecht, T., Lynn, S. J., Lilienfeld, S. O., \& Merckelbach, H. (2008). Cognitive processes in dissociation: an analysis of core theoretical assumptions. Psychological Bulletin, 134(5), 617647. doi:10.1037/0033-2909.134.5.617

Goff, D. C., Olin, J. A., Jenike, M. A., Baer, L., \& Buttolph, M. L. (1992). Dissociative symptoms in patients with obsessivecompulsive disorder. Journal of Nervous and Mental Disease, 180(5), 332-337. doi:Doi 10.1097/00005053-19920500000008

Grabe, H. J., Goldschmidt, F., Lehmkuhl, L., Gansicke, M., Spitzer, C., \& Freyberger, H. J. (1999). Dissociative symptoms in obsessive-compulsive dimensions. Psychopathology, 32(6), 319-324. doi:Doi 10.1159/000029105

Guidano, V. F., \& Liotti, G. (1983). Cognitive processes and emotional disorders. New York, NY: Guilford.
Holmes, E. A., Brown, R. J., Mansell, W., Fearon, R. P., Hunter, E. C. M., Frasquilho, F., \& Oakley, D. A. (2005). Are there two qualitatively distinct forms of dissociation? A review and some clinical implications. Clinical Psychology Review, 25(1), 1-23. doi:10.1016/j.cpr.2004.08.006

Kadak, M. T., Nasiroglu, S., Boysan, M., \& Aydin, A. (2013). Risk factors predicting posttraumatic stress reactions in adolescents after 2011 Van earthquake. Comprehensive Psychiatry, 54(7), 982-990. doi:10.1016/j.comppsych.2013.04.003

Lanius, R. A., Vermetten, E., Loewenstein, R. J., Brand, B., Schmahl, C., Bremner, J. D., \& Spiegel, D. (2010). Emotion modulation in PTSD: Clinical and neurobiological evidence for a dissociative subtype. American Journal of Psychiatry, 167(6), 640-647. doi:10.1176/appi.ajp.2009.09081168

Liotti, G. (2004). Trauma, dissociation, and disorganized attachment: Three strands of a single braid. Psychotherapy, 41(4), 472-486. doi:10.1037/0033-3204.41.4.472

Lochner, C., du Toit, P. L., Zungu-Dirwayi, N., Marais, A., van Kradenburg, J., Seedat, S., ... Stein, D. J. (2002). Childhood trauma in obsessive-compulsive disorder, trichotillomania, and controls. Depression and Anxiety, 15(2), 66-68. doi:10.1002/ da.10028

Lochner, C., Seedat, S., Hemmings, S. M. J., Kinnear, C. J., Corfield, V. A., Niehaus, D. J. H., . . Stein, D. J. (2004). Dissociative experiences in obsessive-compulsive disorder and trichotillomania: Clinical and genetic findings. Comprehensive Psychiatry, 45(5), 384-391. doi:10.1016/j.comppsych.2004.03.010

Maaranen, P., Tanskanen, A., Hintikka, J., Honkalampi, K., Haatainen, K., Koivumaa-Honkanen, H., \& Viinamaki, H. (2008). The course of dissociation in the general population: a 3-year follow-up study. Comprehensive Psychiatry, 49(3), 269-274. doi:10.1016/j.comppsych.2007.04.010

Mataix-Cols, D., do Rosario-Campos, M. C., \& Leckman, J. F. (2005). A multidimensional model of obsessive-compulsive disorder. American Journal of Psychiatry, 162(2), 228-238. doi:DOI 10.1176/appi.ajp.162.2.228

Mathews, C. A., Kaur, N., \& Stein, M. B. (2008). Childhood trauma and obsessive-compulsive symptoms. Depression and Anxiety, 25(9), 742-751. doi:10.1002/da.20316

Muller, J., \& Roberts, J. E. (2005). Memory and attention in obsessive-compulsive disorder: a review. Journal of Anxiety Disorders, 19(1), 1-28. doi:10.1016/j.janxdis.2003.12.001

Norton, G. R., Ross, C. A., \& Novotny, M. F. (1990). Factors That Predict Scores on the Dissociative Experiences Scale. Journal of Clinical Psychology, 46(3), 273-277. doi:Doi $10.1002 / 1097-4679(199005) 46: 3<273:$ : A id Jclp2270460304>3.0.Co;2-X

Ogawa, J. R., Sroufe, L. A., Weinfield, N. S., Carlson, E. A., \& Egeland, B. (1997). Development and the fragmented self: longitudinal study of dissociative symptomatology in a nonclinical sample. Development and Psychopathology, 9(4), 855-879.

Paradisis, S. M., Aardema, F., \& Wu, K. D. (2015). Schizotypal, dissociative, and imaginative processes in a clinical OCD sample. Journal of Clinical Psychology, 71(6), 606-624.

Pica, M., Beere, D., \& Maurer, L. (1997). The overlap between dissociative and obsessive-compulsive disorders: A theoretical link. Dissociation, 10, 38-43.

Rachman, S., \& De Silva, P. (1978). Abnormal and normal obsessions. Behaviour Research and Therapy, 16, 233-248. doi:10.1016/0005-7967(78)90022-0

Ross, C. A., Joshi, S., \& Currie, R. (1990). Dissociative experiences in the general population. American Journal of Psychiatry, 147(11), 1547-1552. doi:https://doi.org/10.1176/ajp.147.11.1547 
Rufer, M., Fricke, S., Held, D., Cremer, J., \& Hand, I. (2006). Dissociation and symptom dimensions of obsessivecompulsive disorder - A replication study. European Archives of Psychiatry and Clinical Neuroscience, 256(3), 146-150. doi:10.1007/s00406-005-0620-8

Salkovskis, P. M., \& Harrison, J. (1984). Abnormal and normal obsessions: A replication. Behaviour Research and Therapy, 22(5), 549-552. doi:Doi 10.1016/0005-7967(84)90057-3

Schimmenti, A., \& Caretti, V. (2016). Linking the overwhelming with the unbearable: Developmental trauma, dissociation, and the disconnected self. Psychoanalytic Psychology, 33(1), $106-$ 128. doi:10.1037/a0038019

Soffer-Dudek, N. (2014). Dissociation and dissociative mechanisms in panic disorder, obsessive-compulsive disorder, and depression: A review and heuristic framework. Psychology of Consciousness: Theory, Research, and Practice, 1(3), 243. doi: $10.1037 /$ cns 0000023

Soffer-Dudek, N., Lassri, D., Soffer-Dudek, N., \& Shahar, G. (2015). Dissociative absorption: An empirically unique, clinically relevant, dissociative factor. Consciousness and Cognition, 36, 338-351. doi:10.1016/j.concog.2015.07.013

Tapancı, Z., Yıldırım, A., \& Boysan, M. (2018). Neurological soft signs, dissociation and alexithymia in patients with obsessivecompulsive disorder (OCD) and healthy subjects. Psychiatry Research.
Van Oppen, P. (1992). Obsessions and compulsions: dimensional structure, reliability, convergent and divergent validity of the Padua Inventory. Behaviour Research and Therapy, 30, 631637.

Vanderlinden, J., Van der Hart, O., \& Varga, K. (1996). European studies of dissociation. In L. K. Michelson \& W. J. Ray (Eds.), Handbook of dissociation (pp. 25-49). New York, NY: Springer.

Waller, N. G., Putnam, F. W., \& Carlson, E. B. (1996). Types of dissociation and dissociative types: A taxometric analysis of dissociative experiences. Psychological Methods, 1(3), 300321. doi:Doi 10.1037/1082-989x.1.3.300

Watson, D., \& Wu, K. D. (2002). Development and validation of the Schedule of Compulsions, Obsessions, and Pathological Impulses (SCOPI). Unpublished manuscript, Department of Psychology, University of lowa, lowa City.

Watson, D., Wu, K. D., \& Cutshall, C. (2004). Symptom subtypes of obsessive-compulsive disorder and their relation to dissociation. Journal of Anxiety Disorders, 18(4), 435-458. doi:10.1016/S0887-6185(03)00029-X

Yargic, L. I., Tutkun, H., \& Sar, V. (1995). The reliability and validity of the Turkish version of the Dissociative Experiences Scale. Dissociation, 8, 10-13. 


\section{APPENDIX}

\section{Van Obsessional Dissociation Questionnaire (VOD-Q)}

Obsessions:

U Unwanted, recurrent and persistent thoughts, images or urges which are intrusive and unacceptable, and lead to pronounced distress (i.e., harm a person, responsible for a harm, contamination with germs, washing hands or checking doors over and over again, etc).

These thoughts are seen as irrational; however, people feel compelled to ponder or do these things.

This questionnaire is interested in how often these experiences happen to you. Using the scale below, please indicate to what degree the experience in each item applies to you:

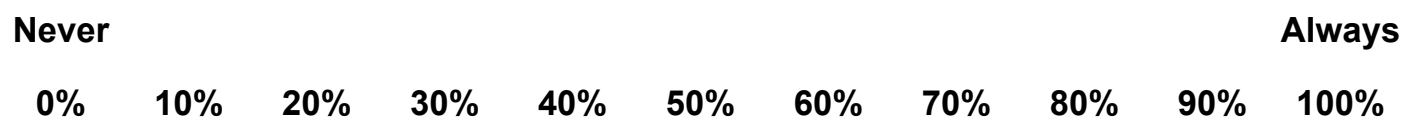

1. While I am working or in a social situation, I suddenly find myself struggling with an unwanted obsessive thought or reliving the moment of an intrusion that occur over and over again.
$0 \%$
$10 \%$
$20 \%$
$30 \%$
$40 \%$
$50 \%$
$60 \%$
$70 \%$
$80 \%$
$90 \% \quad 100 \%$

2. When my mind is busy to do things without a mistake or to do everything just right, there are times that I am not aware of people around me, or that I don't hear people speaking to me.

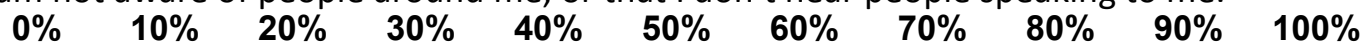

3. While I'm driving or travelling, I suddenly find myself not remembering what has happened during all or part of the trip because of being immersed in unwanted obsessive thoughts.
$0 \%$
$10 \%$
$20 \%$
$30 \%$
$40 \%$
$50 \%$
$60 \%$
$70 \%$
$80 \%$
$90 \% \quad 100 \%$

4. While I am doing something (eg., watching TV, listening to something, talking to someone), I suddenly become immersed in unwanted obsessive thoughts.
$0 \%$
$10 \%$
$20 \%$
$30 \%$
$40 \%$
$50 \%$
$60 \% \quad 70 \%$
$80 \% \quad 90 \% \quad 100 \%$

5. As I get fixated on a detail, even though it is trivial or very minor, I wander off into this detail even in the midst of an important meeting or work.
$0 \%$
$10 \%$
$20 \%$
$30 \%$
$40 \%$
$50 \%$
$60 \%$
$70 \%$
$80 \% \quad 90 \% \quad 100 \%$

6. While I am going things over and over again in my mind that I have already done (eg, locking the door, turning the gas off), I suddenly find myself in another place or realize that a long time passed in the same position.
$0 \% \quad 10 \%$
$20 \%$
$30 \%$
$40 \%$
$50 \%$
$60 \%$
$70 \%$
$80 \% \quad 90 \% \quad 100 \%$

7. I find that even though my mind is occupied with daily activities, at the meantime, it is busy with many unwanted obsessive thoughts.
$0 \%$
$10 \%$
$20 \% \quad 30 \%$
$40 \%$
$50 \%$
$60 \%$
$70 \%$
$80 \%$
$90 \%$
$100 \%$ 
8. When I can't find something that I was looking for or that could be necessary later, I find it difficult to get rid of thinking about it.

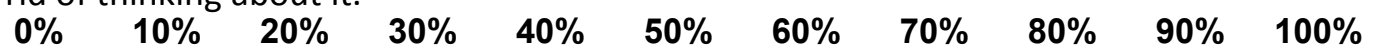

9. Due to that all my attention is absorbed by unwanted obsessive thoughts, I can't concentrate on anything else.

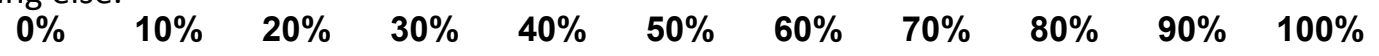

10. There are times I find myself repeating a number, name or word that I don't notice what is happening around me.

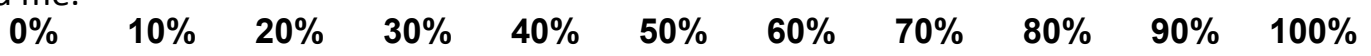

11. If I don't complete an action in just right number or order that I feel compelled, I cannot help thinking about it.

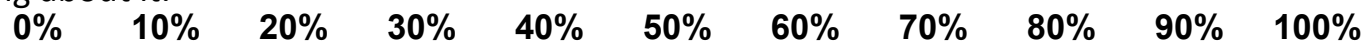

12. While I am imagining infinite possibilities related to contaminating things (eg, saliva, bodily fluids), I lose awareness of time or place.

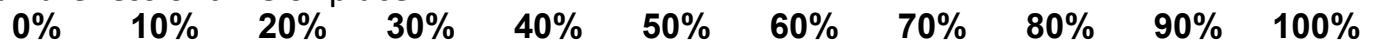

13. There are times I find myself counting or following certain rituals in a fixed order in performing everyday tasks that I forget what I have been doing.

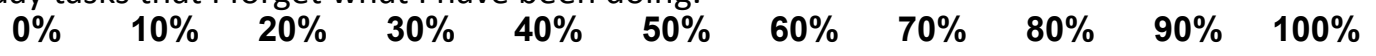

14. While I am checking something (eg, closing doors, turning off taps, gas, etc), I suddenly realize that a considerable time has lapsed.

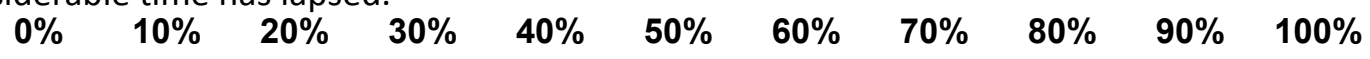

15. When I become obsessed in a detail, even it is trivial or ridiculous; I can forget works or appointments crucial for me.

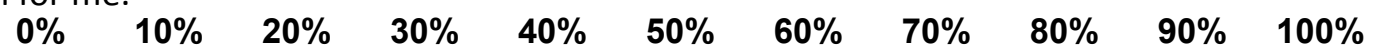

16. There are times I lose awareness of what is happening around me while re-experiencing an interpersonal scene or repeating words over and over again.
$0 \%$
$10 \%$
$20 \%$
$30 \%$
$40 \%$
$50 \%$
$60 \% \quad 70 \%$
$80 \% \quad 90 \% \quad 100 \%$

17. I am cut off from normal life experiencing dream-like states, when considering probabilities of potential outcomes of a decision even making a simple one.
$0 \%$
$10 \%$
$20 \% \quad 30 \%$
$40 \%$
$50 \%$
$60 \%$
$70 \% \quad 80 \% \quad 90 \% \quad 100 \%$

18. There are times I find myself being wandered off, neutralizing an unwanted thought.
$0 \%$
$10 \%$
$20 \% \quad 30 \%$
$40 \%$
$\mathbf{5 0 \%}$
$60 \%$
$70 \%$
$\mathbf{8 0 \%}$
$90 \% \quad 100 \%$ 
19. There are times I cannot differentiate between the actual place where I am and the place where I experienced an intrusion that I can't help thinking (eg., the place where I think I am contaminated by germs, the kitchen in which I turned off the stove).
$0 \%$
$10 \% \quad 20 \%$
$30 \%$
$40 \% \quad 50 \%$
$60 \% \quad 70 \%$
$80 \% \quad 90 \% \quad 100 \%$

20. There are times I cannot be sure whether I have actually experienced things or situations that have popped into my mind.

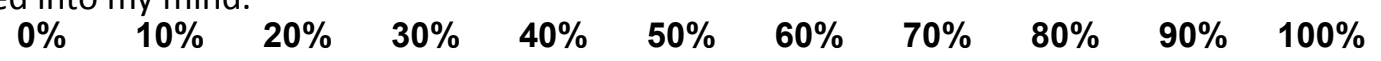

21. When I cannot get rid of unwanted obsessive thoughts, I have difficulty being sure whether an event I heard or news I read is real or whether they are just in my thoughts.

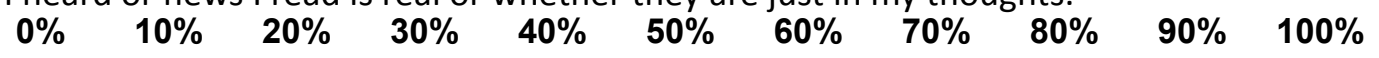

22. When I cannot get rid of unwanted obsessive thoughts, there are times that I cannot remember whether I have actually done something or whether I just thought about it (eg. Did I pay the bill or just think of it?)

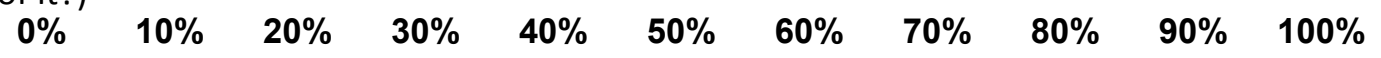

23. When I cannot get rid of unwanted obsessive thoughts, I feel like that I' $m$ in the space or in a dream.

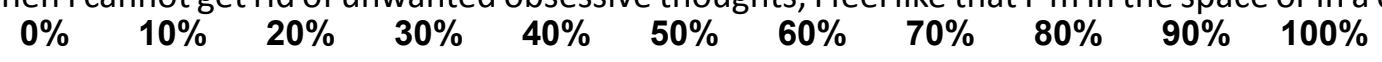

24. When I cannot get rid of unwanted obsessive thoughts, I feel like that I'm looking at the world through a haze.
$0 \% \quad 10 \%$
$10 \% \quad 20 \%$
$20 \% \quad 30 \%$
$40 \% \quad 50 \%$
$60 \% \quad 70 \%$
$80 \% \quad 90 \% \quad 100 \%$

25. When I cannot get rid of unwanted obsessive thoughts, I feel like that objects and people around me, and my surroundings are unreal.
$0 \% \quad 10 \% \quad 20 \% \quad 30 \%$
$40 \%$
$50 \%$
$60 \%$
$70 \% \quad 80 \% \quad 90 \% \quad 100 \%$

26. When I cannot get rid of unwanted obsessive thoughts, I feel like that I completely lose awareness of time.

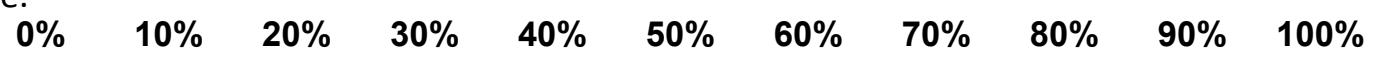

27. When I cannot get rid of unwanted obsessive thoughts, I don't feel pain or cold.
$0 \%$
$10 \%$
$20 \%$
$30 \%$
$40 \%$
$50 \%$
$60 \% \quad 70 \%$
$80 \% \quad 90 \% \quad 100 \%$

28. When I cannot get rid of unwanted obsessive thoughts, I hear sounds warning me that I could lose my self-control, or harm someone else or that I could behave in ways that I have never done before.
$0 \%$
$10 \%$
$20 \% \quad 30 \%$
$40 \%$
$50 \%$
$60 \% \quad 70 \%$
$80 \% \quad 90 \% \quad 100 \%$

29. When I cannot get rid of unwanted obsessive thoughts, while talking, I feel as though it was someone else talking, but not me.
$0 \%$
$10 \%$
$20 \% \quad 30 \%$
$40 \%$
$50 \%$
$60 \%$
$70 \%$
$80 \%$
$90 \% \quad 100 \%$ 
30. When I cannot get rid of unwanted obsessive thoughts or imaginings from my mind, I realize that I have been talking to myself.

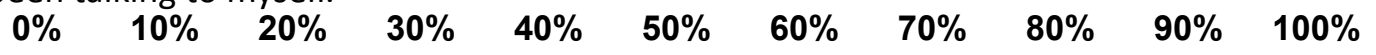

31. I hear unpleasant or unwanted thoughts or words vaguely reflected in my mind as if someone is talking to me.

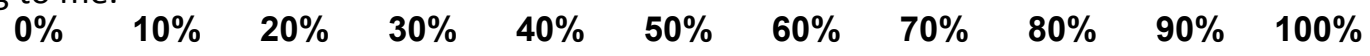

32. When I cannot get rid of unwanted obsessive thoughts or imaginings, there are times that I don't recognize myself when I look in the mirror.

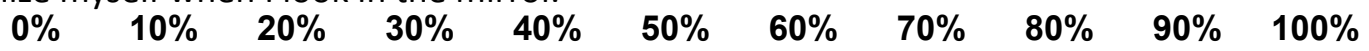

33. When I cannot get rid of unwanted obsessive thoughts, I feel as if I was looking at myself from the outside of my body, watching a movie scene.
$0 \%$
$10 \%$
$20 \% \quad 30 \%$
$40 \% \quad 50 \%$
$60 \% \quad 70 \%$
$80 \% \quad 90 \% \quad 100 \%$

34. When I cannot get rid of unwanted obsessive thoughts, it seems like that I have lost control and done things I would never normally do (eg, throw myself or someone else in front of a car, strip off my clothes in a crowded place).

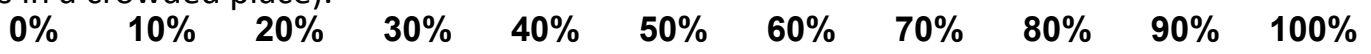

35. I feel as if there were people or things inside me that force me do things that are completely irrational and I really don't want to do.
$0 \%$
$10 \%$
$20 \%$
$30 \%$
$40 \%$
$50 \%$
$60 \%$
$70 \%$
$80 \% \quad 90 \% \quad 100 \%$

36. When I cannot get rid of unwanted obsessive thoughts, my body seems strange, vague and unfamiliar to me.

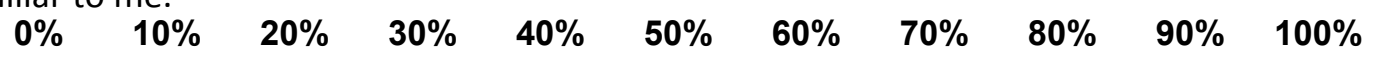

37. When I cannot can get rid of unwanted obsessive thoughts, I feel like that the things I have said or done belong to someone else.
$0 \%$
$10 \%$
$20 \%$
$30 \% \quad 40 \%$
$50 \%$
$60 \% \quad 70 \%$
$80 \% \quad 90 \% \quad 100 \%$

38. When I cannot get rid of unwanted obsessive thoughts, I have the experience of feeling as though there were other minds in my head creating strange, unpleasant, intrusive thoughts or imaginings.
$0 \%$
$10 \% \quad 20 \%$
$30 \%$
$40 \%$
$50 \%$
$60 \%$
$70 \%$
$80 \%$
$90 \% 100 \%$

39. When I cannot get rid of unwanted obsessive thoughts, I realize that I have easily performed and completed some things which would normally be difficult for me to do (eg, sport, work).
$0 \%$
$10 \%$
$20 \%$
$30 \%$
$40 \%$
$50 \%$
$60 \%$
$70 \%$
$80 \%$
$90 \% \quad 100 \%$

40. When I cannot get rid of unwanted obsessive thoughts, I feel that my emotions, thoughts and behaviours are functioning on their own independent from each other.
$0 \%$
$10 \%$
$20 \%$
$30 \%$
$40 \%$
$50 \%$
$60 \%$
$70 \%$
$80 \% \quad 90 \% \quad 100 \%$ 
41. When I cannot get rid of unwanted obsessive thoughts, I feel that my body is moving on its own out of my control.

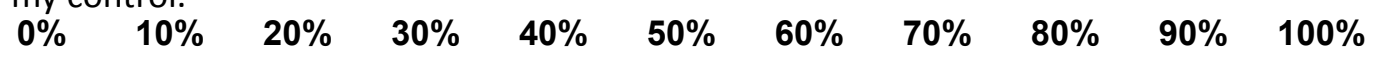

42. When I cannot get rid of unwanted obsessive thoughts, there are times I have remained frozen without moving for a long time.

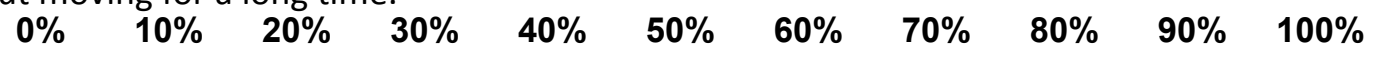

43. When I cannot get rid of unwanted obsessive thoughts, I am said that I have behaved to close friends or family members as if I did not know them before.
$0 \%$
$10 \%$
$20 \%$
$30 \%$
$40 \%$
$50 \%$
$60 \%$
$70 \% \quad 80 \% \quad 90 \% \quad 100 \%$

44. When I cannot get rid of unwanted obsessive thoughts, I may suddenly find myself in an unfamiliar place.

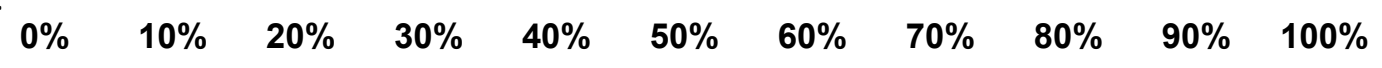

45. When my mind overloads with obsessive thoughts, I don't remember what I have done, even I have checked several times (eg, turning off the gas, locking the door).

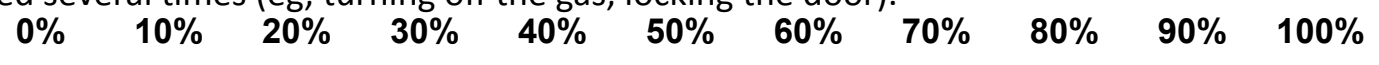

Reference: Murat Boysan, Abdullah Yıldırım, Lütfullah Beşiroğlu, Mehmet Celal Kefeli, Mücahit Kağan (2017). Development and Preliminary Psychometric Properties of an Instrument for the Measurement of Obsessional Dissociative Experiences: The Van Obsessional Dissociation Questionnaire (VOD-Q). Psychiatric Quarterly, https://doi.org/10.1007/s11126-017-9555-2

Important note: Please keep in mind that the VOD-Q form presented below represents a translation to English. However, the psychometric properties of this translation have not been investigated in an English speaking population that researchers should be cautious while using this form. Probably, the statements of the VOD-Q would need redaction to obtain an exact semantic equivalence. Due to the reason that some other authors would like to reassess English version of the VOD-Q or to translate the questionnaire into other languages, we provided the original Turkish version of the scale. 


\section{VOD-Q Scoring}

\section{VOD-Q Global:}

$($ Item $1+$ Item $2+$ Item $3+\ldots+$ Item $43+$ Item $44+$ Item 45$) / 45=$

\section{Obsessional Absorption}

$($ Item $1+$ Item $2+$ Item $3+$ Item $4+$ Item $5+$ Item $7+$ Item $8+$ Item $9+$ Item $10+$ Item $11+$ Item $16+$ Item $17+$ Item $18+$ Item 45) $/ 14=$

\section{Obsessional Depersonalization / Derealization}

$($ Item $23+$ Item $24+$ Item $25+$ Item $26+$ Item $27+$ Item $28+$ Item $29+$ Item $30+$ Item $31+$ Item 32 + Item 33 + Item 34+ Item 35 + Item 36 + Item 37+ Item 38 + Item 39 + Item 40+ Item $41+$ Item $42+$ Item 43+ Item 44) / $22=$

\section{Obsessional Amnesia}

$($ Item $6+$ Item $12+$ Item $13+$ Item 14+ Item $15+$ Item $19+$ Item $20+$ Item $21+$ Item 22) $/ 9$ $=$ 


\section{Van Obsesyonel Disosiyasyon Ölçeği (VOD-Ö)}

Takıntılar (Obsesyonlar):

Aniden gelen, kabul edilemez ve ciddi psikolojik strese neden olabilecek istenmeyen, tekrar edici ve dirençli düşünce, hayal veya dürtülerdir(Örn., birine zarar vermek, zarardan sorumlu olmak, mikrop bulaşması, tekrar tekrar elleri yıkamak veya kapıyı kontrol etmek, vb.).

Bu düşünceler mantıksız gelir; buna karşın, insanlar bunlar üzerinde kafa yormaya veya bunları yapmaya kendilerini zorunlu hisseder.

Aşağıda sıralanan durumları ne sıklıkta yaşadığınızı aşağıda yer alan skalaya göre değerlendiriniz:

Hiçbir zaman

$\begin{array}{lllllllllll}\% 0 & \% 10 & \% 20 & \% 30 & \% 40 & \% 50 & \% 60 & \% 70 & \% 80 & \% 90 & \% 100\end{array}$

1. Çalışırken veya insanlarla birlikteyken bir anda kendimi, tekrar eden istenmeyen takıntılı bir düşünceyle uğraşırken veya obsesyonun kafama takıldığı anı tekrar tekrar yaşarken bulurum.
$\% 0$
$\% 10 \% 20$
$\% 30$
$\% 40$
$\% 50$
$\% 60$
$\% 70$
$\% 80 \quad \% 90 \quad \% 100$

2. Zihnimde bir şeyleri hatasız veya tam doğru yapabilmekle meşgulken çevremde olup bitenleri fark etmediğim, bana seslenenleri veya benimle konuşanları duymadığım anlar vardır.

$\begin{array}{lllllllllll}\% 0 & \% 10 & \% 20 & \% 30 & \% 40 & \% 50 & \% 60 & \% 70 & \% 80 & \% 90 & \% 100\end{array}$

3. Araba sürerken veya bir yolculuk sırasında istenmeyen takıntılı düşüncelere kapılıp gittiğim için yol boyunca ne olduğunu hatırlamadığımı fark ederim.

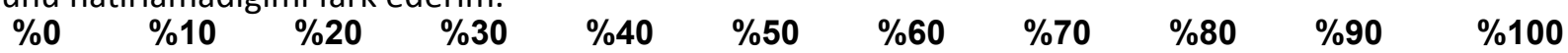

4. Bir şeyler yaparken (örn., televizyonun karşısında, bir şey dinlerken veya bir başkasıyla karşılıklı konuşurken), aniden istenmeyen takıntılı düşüncelere dalar giderim.

$$
\begin{array}{lllllllllll}
\% 0 & \% 10 & \% 20 & \% 30 & \% 40 & \% 50 & \% 60 & \% 70 & \% 80 & \% 90 & \% 100
\end{array}
$$

5. Gereksiz veya çok küçük olduğunu iyi bildiğim bir ayrınttya bile takılsam çok önemli bir görüşme veya iş sırasında bile dalıp, zihnimde bu ayrıntıyla uğraşmaya başlarım.

$\begin{array}{lllllllllll}\% 0 & \% 10 & \% 20 & \% 30 & \% 40 & \% 50 & \% 60 & \% 70 & \% 80 & \% 90 & \% 100\end{array}$

6. Yaptı̆ım bir şeyleri (kapıyı kilitleme, tüpü kapatma, vb.) zihnimde tekrar tekrar canlandırırken bir anda kendimi başka bir yerde bulduğum veya olduğum yerde çok uzun zaman geçirdiğim zamanlar vardır.
$\% 0$
$\% 10$
\%20
\%30
$\% 40$
$\% 50$
$\% 60$
$\% 70$
$\% 80$
$\% 90$
$\% 100$

7. Kafam günlük işlerimle meşgulken aynı zamanda da istenmeyen takıntılı pek çok düşünceyle zihnimin meşgul olduğunu fark ederim.

$$
\begin{array}{ccccccccccc}
\% 0 & \% 10 & \% 20 & \% 30 & \% 40 & \% 50 & \% 60 & \% 70 & \% 80 & \% 90 & \% 100
\end{array}
$$

8. Aradığım veya sonrasında bana lazım olabileceğini düşündüğüm bir şeyi bulamadığımda, ne yaparsam yapayım kendimi o şey üzerinde düşünürken bulurum.

$\begin{array}{lllllllllll}\% 0 & \% 10 & \% 20 & \% 30 & \% 40 & \% 50 & \% 60 & \% 70 & \% 80 & \% 90 & \% 100\end{array}$

9. Bütün dikkatim istenmeyen takıntılı düşünce tarafindan çekildiği için başka hiçbir şeye konsantre olamam.

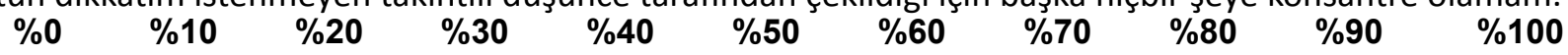


10. Gün içinde kafama takılan bir sayı, isim veya kelimeyi tekrarlarken dalıp gittiğim ve çevremde olup biteni fark etmediğim zamanlar vardır.

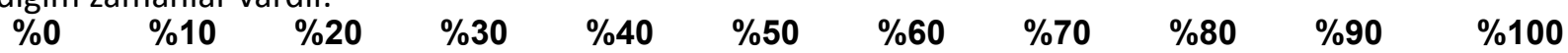

11. Belirli bir sayıda veya sırada yapmam gerektiğini hissettiğim bir davranışı tam doğru bir şekilde yapamadığımda, ne yaparsam yapayım kendimi bu davranışı düşünürken bulurum.
$\% 0$
$\% 10$
$\% 20$
$\% 30$
$\% 40$
$\% 50$
$\% 60$
$\% 70$
$\% 80$
$\% 90 \quad \% 100$

12. Üzerime bulaşan bir şeylerle ilişkili (örn., tükürük, vücut sıvısı vb.) sonsuz olasılıklar ve sonuçlar üretirken, bulunduğum yeri veya zamanı unuttuğum olur.
$\% 0$
$\% 10$
$\% 20$
$\% 30$
$\% 40$
$\% 50$
$\% 60$
$\% 70$
$\% 80 \quad \% 90 \quad \% 100$

13. Günlük işlerimi yaparken kendimi saymaya veya belirli bir sırayı veya düzeni takip etmeye kaptırıp, ne yaptı̆̆ımı unuttuğum zamanlar vardır.
$\% 0 \quad \% 10 \quad \% 20$
$\% 30$
$\% 40$
$\% 50$
$\% 60$
$\% 70$
$\% 80$
$\% 90$
$\% 100$

14. Bir şeyleri (örn., musluk, tüp, kapı vb.) kontrol ederken bir anda çok uzun bir sürenin geçtiğini fark ederim.

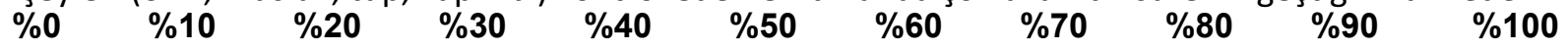

15. Gereksiz veya çok küçük bir ayrıntıya bile takılırsam, benim için hayati öneme sahip işleri veya randevuları bile unutabilirim.
$\% 0 \quad \% 10$
$\% 20$
\%30
$\% 40$
$\% 50$
$\% 60$
$\% 70$
$\% 80 \quad \% 90$
$\% 100$

16. Yaptığım bir görüşmeyi veya ağzımdan çıkan sözleri kafamda tekrar ederken çevremde olan biteni fark etmediğim anlar vardır.
$\% 0 \quad \% 10$
$\% 20$
$\% 30$
$\% 40$
$\% 50$
$\% 60$
$\% 70$
$\% 80$
$\% 90$
$\% 100$

17. Alacağım basit bir kararda bile olası sonuçları hesaplarken normal hayattan kopup sanki başka bir rüya aleminde yaşamaya başlarım.
$\% 0 \quad \% 10 \quad \% 20$
$\% 30 \quad \% 40$
$\% 50$
$\% 60 \quad \% 70$
$\% 80$
$\% 90 \quad \% 100$

18. İstenmeyen bir düşünceyi düzeltebilmek (nötüleştirmek) için uğraşırken dalıp gittiğim anlar vardır.
$\% 0$
$\% 10$
$\% 20$
$\% 30$
$\% 40$
$\% 50$
$\% 60$
$\% 70$
$\% 80$
$\% 90$
$\% 100$

19. Gerçekte içinde bulunduğum mekânla, zihnimden uzaklaştıramadığım bir şeyin veya durumun yaşandığı mekânı (örn., mikrop kaptığımı düşündüğüm bir yer, kapattı̆ım ocağın bulunduğu mutfak, vb.) ayırt edemediğim zamanlar vardır.
$\% 0 \quad \% 1$
$\% 20$
$\% 30$
$\% 40$
$\% 50$
$\% 60$
$\% 70$
$\% 80$
$\% 90 \quad \% 100$

20. Zihnimi takıntılı bir şekilde meşgul eden şeylerin veya durumların gerçekte yaşanıp yaşamadığımdan emin olamadığım zamanlar vardır.
$\% 0 \quad \% 10 \quad \% 20$
$\% 30$
$\% 40$
$\% 50$
$\% 60$
$\% 70$
$\% 80$
$\% 90 \quad \% 100$

21.İstenmeyen takıntılı düşünceleri zihnimden uzaklaşttramadığım zamanlarda, duyduğum bir olayın veya okuduğum bir haberin benim düşüncem mi yoksa gerçek mi olduğunu ayırmakta güçlük çekerim. $\%$
$\% 10$
$\% 20$
$\% 30$
$\% 40$
$\% 50$
$\% 60$
$\% 70$
$\% 80$
$\% 90 \quad \% 100$

22. İstenmeyen takıntılı düşünceleri zihnimden uzaklaştıramadığım zamanlarda, bir işi gerçekten yaptım mı yoksa sadece yapmayı aklımdan mı geçirdiğimi (örn., faturayı ödedim mi yoksa sadece düşündüm mü) hatırlayamadığım anlar vardır.

$\begin{array}{lllllllllll}\% 0 & \% 10 & \% 20 & \% 30 & \% 40 & \% 50 & \% 60 & \% 70 & \% 80 & \% 90 & \% 100\end{array}$

23. İstenmeyen takıntılı düşünceleri zihnimden uzaklaştıramadığım zamanlarda sanki uzaydaymışım veya rüyadaymışım gibi gelir.

\begin{tabular}{|c|}
\hline $0 \%$ \\
\hline
\end{tabular}


24. İstenmeyen takıntılı düşünceleri zihnimden uzaklaştıramadığım zamanlarda dünyaya puslu bir sis perdesinin ardından bakıyormuşum gibi gelir.

$$
\begin{array}{lllllllllll}
\% 0 & \% 10 & \% 20 & \% 30 & \% 40 & \% 50 & \% 60 & \% 70 & \% 80 & \% 90 & \% 100
\end{array}
$$

25. İstenmeyen takıntılı düşünceleri zihnimden uzaklaşttramadığım zamanlarda çevremdeki nesnelerin, insanların ve beni çevreleyen dünyanın gerçek olmadığı hissine kapılırım.

$$
\begin{array}{lllllllllll}
\% 0 & \% 10 & \% 20 & \% 30 & \% 40 & \% 50 & \% 60 & \% 70 & \% 80 & \% 90 & \% 100
\end{array}
$$

26. İstenmeyen takıntılı düşünceleri zihnimden uzaklaştıramadığım anlarda zaman kavramını tamamen yitirdiğimi hissederim.

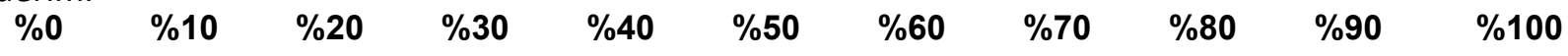

27. İstenmeyen takıntılı düşünceleri zihnimden uzaklaşttramadığım zamanlarda ağrı veya üşüme hissini duymadığım olur.

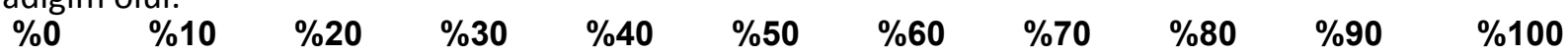

28. İstenmeyen takıntılı düşünceleri zihnimden uzaklaştıramadığım zamanlarda kontrolümü kaybedip kendime veya başkalarına zarar verebileceğim veya hiç olmadık davranışlarda bulunabileceğim konusunda beni uyaran sesler duyarım.

$$
\begin{array}{lllllllllll}
\% 0 & \% 10 & \% 20 & \% 30 & \% 40 & \% 50 & \% 60 & \% 70 & \% 80 & \% 90 & \% 100
\end{array}
$$

29. İstenmeyen takıntılı düşünceleri zihnimden uzaklaşttramadığım zamanlarda konuşurken sanki benden başka birisi konuşuyormuş gibi hissederim.

$$
\begin{array}{lllllllllll}
\% 0 & \% 10 & \% 20 & \% 30 & \% 40 & \% 50 & \% 60 & \% 70 & \% 80 & \% 90 & \% 100
\end{array}
$$

30. İstenmeyen takıntılı düşünceleri veya hayalleri zihnimden uzaklaştıramadığım zamanlarda kendi kendime konuştuğumu fark ederim.

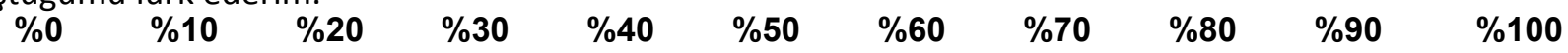

31. Hoşuma gitmeyen veya istemediğim düşünce veya sözcüklerin birisi benimle konuşuyormuşçasına belli belirsiz zihnimde yankılandığını duyarım.

$\begin{array}{lllllllllll}\% 0 & \% 10 & \% 20 & \% 30 & \% 40 & \% 50 & \% 60 & \% 70 & \% 80 & \% 90 & \% 100\end{array}$

32. İstenmeyen takıntılı düşünceleri veya hayalleri zihnimden uzaklaştıramadığım zamanlarda aynaya baktığımda kendimi tanıyamadığım olur.

$$
\begin{array}{lllllllllll}
\% 0 & \% 10 & \% 20 & \% 30 & \% 40 & \% 50 & \% 60 & \% 70 & \% 80 & \% 90 & \% 100
\end{array}
$$

33. İstenmeyen takıntılı düşünceleri zihnimden uzaklaştıramadığım zamanlarda kendimi dışarıdan sanki bir film perdesinde izliyormuşum hissine kapılırım.

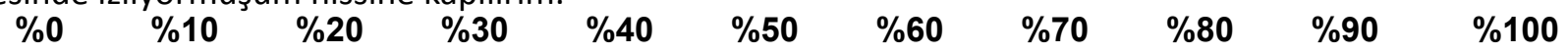

34. İstenmeyen takıntılı düşünceleri zihnimden uzaklaştıramadığım zamanlarda kontrolümü kaybedip normalde asla yapmayacağım şeyleri yapacakmışım (örn., kendimi veya başkasını bir arabanın önüne atmak, insanların içinde soyunmak, vb.) gibi gelir.

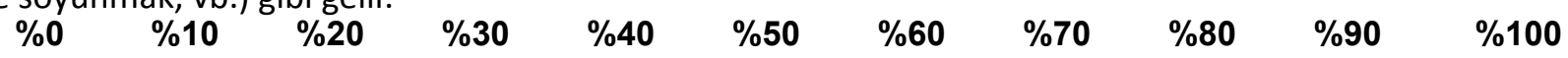

35. İçimde gerçekte bana son derece mantıksı gelen ve yapmak istemediğim şeyleri bana yaptran birileri veya bir şeyler olduğu hissine kapılırım.

$$
\begin{array}{lllllllllll}
\% 0 & \% 10 & \% 20 & \% 30 & \% 40 & \% 50 & \% 60 & \% 70 & \% 80 & \% 90 & \% 100
\end{array}
$$

36. İstenmeyen takıntılı düşünceleri zihnimden uzaklaştıramadığım zamanlarda bedenim tuhaf, belirsiz veya bana yabancı gelir.

$$
\begin{array}{lllllllllll}
\% 0 & \% 10 & \% 20 & \% 30 & \% 40 & \% 50 & \% 60 & \% 70 & \% 80 & \% 90 & \% 100
\end{array}
$$


37. İstenmeyen takıntılı düşünceleri zihnimden uzaklaştıramadığım zamanlarda söylediklerim veya yaptıklarım benden başka birine aitmiş gibi gelir.

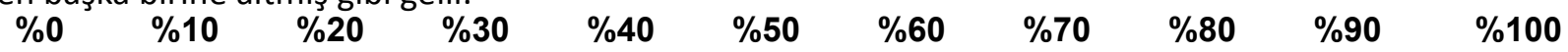

38. İstenmeyen takıntlı düşünceleri zihnimden uzaklaştıramadığım zamanlarda, kafamın içinde bana yabancı ve hoşuma gitmeyen takıntılı düşünceler veya hayaller üreten başka zihinler varmış gibi gelir.

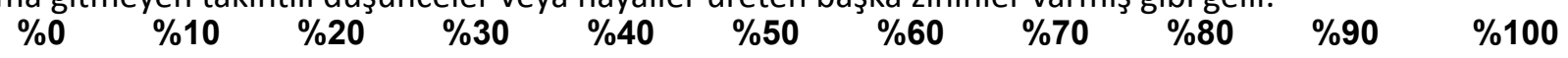

39.İstenmeyen takıntılı düşünceleri zihnimden uzaklaştıramadığım zamanlarda normalde yapmakta zorlanacağım bazı şeyleri çok kolaylıkla yapıp bitirdiğimi fark ederim (örn. spor, iş, v.b.).

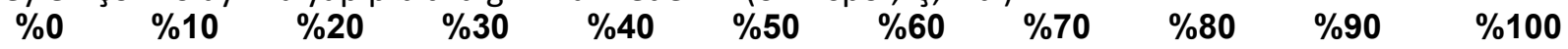

40. İstenmeyen takıntılı düşünceleri zihnimden uzaklaştıramadığım zamanlarda duygu, düşünce veya davranışlarımın birbirinden bağımsız kendi başına hareket ettiği hissine kapılırım.

$$
\begin{array}{lllllllllll}
\% 0 & \% 10 & \% 20 & \% 30 & \% 40 & \% 50 & \% 60 & \% 70 & \% 80 & \% 90 & \% 100
\end{array}
$$

41. İstenmeyen takıntılı düşünceleri zihnimden uzaklaştıramadığım zamanlarda bedenimin benden bağımsız kendi başına hareket ettiği hissine kapılırım.

$$
\begin{array}{lllllllllll}
\% 0 & \% 10 & \% 20 & \% 30 & \% 40 & \% 50 & \% 60 & \% 70 & \% 80 & \% 90 & \% 100
\end{array}
$$

42. İstenmeyen takıntılı düşünceleri zihnimden uzaklaştıramadığım zamanlarda donup hiç kıpırdamadan uzun süre kaldığım anlar vardır.

$\begin{array}{lllllllllll}\% 0 & \% 10 & \% 20 & \% 30 & \% 40 & \% 50 & \% 60 & \% 70 & \% 80 & \% 90 & \% 100\end{array}$

43. İstenmeyen takıntılı düşünceleri zihnimden uzaklaştıramadığım zamanlarda yakın arkadaşlarımı veya aile üyelerini hiç tanımıyormuşum gibi davrandığım söylenir.

$$
\begin{array}{lllllllllll}
\% 0 & \% 10 & \% 20 & \% 30 & \% 40 & \% 50 & \% 60 & \% 70 & \% 80 & \% 90 & \% 100
\end{array}
$$

44. İstenmeyen takıntılı düşünceleri zihnimden uzaklaştıramadığım zamanlarda kendimi bir anda hiç tanımadığım bir yerde bulduğum olur.

$$
\begin{array}{lllllllllll}
\% 0 & \% 10 & \% 20 & \% 30 & \% 40 & \% 50 & \% 60 & \% 70 & \% 80 & \% 90 & \% 100
\end{array}
$$

45. Zihnim takıntılı düşüncelerle çok fazla meşgulken birkaç kez kontrol ettiğim halde (örn., tüpü kapatma, kapıyı kilitleme, vb.) yaptığım şeyi hatırlamadığım olur.

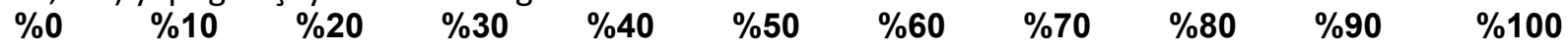

Kaynak: Murat Boysan, Abdullah Yıldırım, Lütfullah Beşiroğlu, Mehmet Celal Kefeli, Mücahit Kağan (2018). Development and Preliminary Psychometric Properties of an Instrument for the Measurement of Obsessional Dissociative Experiences: The Van Obsessional Dissociation Questionnaire (VOD-Q). Psychiatric Quarterly, https://doi.org/10.1007/s11126-017-9555-2 


\section{Alt Ölçeklerin Hesaplanması}

\section{VOD-Q Global:}

(Madde $1+$ Madde $2+$ Madde $3+\ldots+$ Madde $43+$ Madde $44+$ Madde 45) $/ 45$ :

\section{Obsesyonel Absorpsiyon}

(Madde $1+$ Madde $2+$ Madde $3+$ Madde $4+$ Madde $5+$ Madde $7+$ Madde $8+$ Madde $9+$ Madde $10+$ Madde $11+$ Madde $16+$ Madde $17+$ Madde $18+$ Madde 45) $/ 14=$

\section{Obsesyonel Depersonalizasyon / Derealizasyon}

(Madde $23+$ Madde $24+$ Madde $25+$ Madde 26 + Madde $27+$ Madde $28+$ Madde $29+$ Madde $30+$ Madde $31+$ Madde $32+$ Madde $33+$ Madde 34+ Madde $35+$ Madde $36+$ Madde 37+ Madde $38+$ Madde $39+$ Madde 40+ Madde 41 + Madde $42+$ Madde 43+ Madde 44) $/ 22=$

\section{Obsesyonel Amnezi}

(Madde $6+$ Madde $12+$ Madde $13+$ Madde 14+ Madde $15+$ Madde $19+$ Madde $20+$ Madde $21+$ Madde 22) $/ 9=$ 